\title{
Nuclear waste management
}

SIR-Robert Walgate (Nature 314, 396; 1985) drew attention to work conducted by the University of Surrey on the public's attitudes towards the management of nuclear waste. However, there were some understandable misinterpretations in his report (which was derived from an oral presentation) concerning the issue of compensation. This advance note of some of our results should set the record straight.

Compensation may be seen as one possible mechanism for reducing the social inequity that is inevitable when a local community is required to host a nuclear waste repository to meet a national need (or to conform with national policy).

Our national survey asked 1,511 people "Do you think it would be right to give some form of compensation to people living in an area where nuclear waste is to be buried?", to which 66 per cent replied "yes".

They were asked subsequently whether the compensation should be directed towards the community as a whole or to individuals. Respondents were able to select one or other or both of these suggestions -48 per cent endorsed personal and 36 per cent community-directed compensation - so it was incorrect to sum these and imply 84 per cent of the public in our survey "could be bought off".

Additional data can put these particular findings into context. People were asked their reactions to proposals to build a range of facilities within two or three miles of their home:

$\%$ Who would $\%$ Whowould
Fove away (if actually
they could)

Radioactive waste

Nuclear power station

Airport

Prison

Army barracks

Motorway

Industrial estate

$\begin{array}{ll}79 & 73 \\ 66 & 59 \\ 51 & 32 \\ 47 & 32 \\ 32 & 16 \\ 30 & 17 \\ 21 & 11\end{array}$

People were also asked about the likelihood of something going seriously wrong

\section{Old hat}

SIR-P. W. Hawkes, in his review of J. W. Goodman's Statistical Optics (Nature 15 August, p.584), states that books on the subject have only recently begun to appear. However, the text Introduction to Statistical Optics by Edward L. O'Neill (Addison-Wesley) appeared in 1963. I was a student of Dr O'Neill's at Boston University at about that time, and found his presentation of the ideas of statistical optics fascinating. I would like him to be recognized as one of the early authors in this field.

SYlvia L. Boyd PO Box 1050 .

Cambridge, Massachusetts 02238, USA at a radioactive waste site:

$\begin{array}{lcc}\text { Likelihood of accident } & \begin{array}{c}\% \text { Within } \\ 5 \text { years }\end{array} & \begin{array}{c}\% \text { Within } \\ 50 \text { years }\end{array} \\ \text { Very likely } & 10 & 26 \\ \text { Likely } & 12 & 20 \\ \text { Possible } & 38 & 28 \\ \text { Unlikely } & 17 & 9 \\ \text { Very unlikely } & 12 & 6 \\ \text { Don't know } & 12 & 12\end{array}$

Finally, respondents picked out those issues that ought to be addressed by a public inquiry. The rank order is as follows:

$\begin{array}{cl}\text { Rank } & \text { Public inquiry issues } \\ \text { 1. } & \text { Health effect } \\ 2 . & \text { Long-term reliability } \\ 3 . & \text { Effects on nature } \\ 4 . & \text { Suitability of geology } \\ 5 . & \text { Local opinion } \\ 6 . & \text { Transport routes and distance } \\ 7 . & \text { National interest } \\ 8 . & \text { Land use } \\ 9 . & \text { Comparative costs of alternative sites } \\ 10 . & \text { Local employment } \\ 11 . & \text { Compensation for local community }\end{array}$

These findings indicate that radioactive sites are indeed problematic and that from this national sample, health issues are paramount.

Other findings indicate that the sites are likely to generate anxiety not only at the level of "personal safety", but also at the "future character of society" level. Sites are seen as the environmental intrusion most likely to predispose people to move away or protest. However, for many there is neither the luxury to be able to move nor the time or skills to participate actively in the decision process. Compensation is one possible form of mitigation and was certainly not seen as bribery by the majority of our respondents.

T. R. LEE J. BROWN

J. HENDERSON C. MCDERMID H. WhITE

Department of Psychology,

University of Surrey,

Guildford, Surrey GU2 5XH, UK

\section{Values in science}

SIR-The recent debate about values in science in your columns has surprisingly reached one point of consensus - that values should be made as explicit as possible in scientific procedures. One side of the debate would then exorcise them as far as possible, the other would change them or even introduce others. Since the point of agreement transcends both views, it is itself an example of something as valueindependent as possible in this context.

One could derive a semiquantitative figure for the degree to which some experimental result or interpretation is value-independent: perhaps it should be inversely proportional to the number of researchers with antithetical philosophical, social and religious views able to agree on it. On that basis, science has been surprisingly value-independent. Hence, ironically, at a higher level, it is often intensely valued because such consensus is rare.

Total exorcism of values from science? The demons may always lurk beyond our consensus or even in it. But I thought the consensus principle meant we should exclude such demons as far as possible from the charmed circle - and then deliberately invoke them afterwards from its relative safety?

To paraphrase St Augustine, love consensus, then do as you will.

International Laboratory of Marine

Radioactivity,

Museé Océanographique,

Monaco-ville,

Principality of Monaco

\section{Selenium-enriched?}

SIR-A recent US Geological Survey report (S.J. Deverell et al. USGS Water Resources Investigations Report 84-4319. Sacramento, California, November 1984) listed concentrations of selenium found in farm irrigation drain sumps in the San Luis Drain service area on the Panoche Fan. These showed concentrations of selenium as high as 3,800 micrograms per litre.

On 26 July 1985 I filmed tomatoes being harvested in the same area. I am not Paracelsus but I would rather Thomas Jukes (Nature 22 August. p.673) ate them than I did.

Michael Andrews (Senior Producer)

Natural History Unit,

British Broadcasting Corporation.

Broadcasting House,

Whiteladies Road.

Bristol BS8 2LR, UK

\section{Chauvinism in the air}

SIR-The first sentence in your unsigned Opinion column of 15 August (p. 566) entitled "Geostationary blues" reads: "A World Administrative Radio Conference of the International Telecommunication Union must rank with anything on the subject of Canada as the surest way for newspapers to lose readers". This rather disingenuous statement seems surprising in the pages of the self-proclaimed "International Weekly Journal of Science". More so. since Nature has its headquarters in London: one might interpret the aside as the jealous rejoinder of the failing parent to the thriving child.

Harrard Medical School. BarkY T. SMITH

Joint Program in Neonatology:

75 Francis Street.

Boston.

Massachusetts 02115. USA 